\title{
Utilization of Household Waste as Economic Added Value in Community Care for the Environment Sumber Subdistrict Cirebon Regency
}

\author{
Syaeful Bakhri ${ }^{1, a)}$, and Dangi ${ }^{2}$ \\ ${ }^{1}$ Program Studi S1 Ekonomi Syariah IAIN Syekh Nurjati Cirebon, Cirebon, Indonesia \\ ${ }^{2}$ Karang Taruna Kabupaten Cirebon, Cirebon, Indonesia \\ a)Corresponding author: sultan01aulia@yahoo.com
}

\begin{abstract}
The purpose of this activity is to convey the success of the Kopeling youth program (Community Care for the Environment) along with all the people who have supported them, especially those in the RT.05/RW.05 Kelurahan Sumber to convert household waste into compost and catfish farming feed to have a selling value. The research method uses a qualitative approach with the Participatory Research Appraisal research design through the Participatory Rural Appraisal method. This research was conducted on Kopeling youth and communities in the neighborhood RT.05/RW.05 Kelurahan Sumber. The findings obtained from this activity are that Kopeling and related communities have active participation and real motivation to minimize the problem of piles of garbage, especially household waste, to be something of economic value.
\end{abstract}

Keywords: Household Waste, Economical Value

\section{INTRODUCTION}

Garbage is a thorny problem in Indonesia. Population growth and economic activity are thought to be the drivers of the increase in the rate of waste generation (Indartik et al., 2018). Population growth, changes in consumption patterns, and people's lifestyles have increased the amount of waste generation, types, and diversity of waste characteristics (Marliani, 2014). Most of the waste generated, household (organic) and (an-organic) waste, has not been appropriately managed. It still ends up in the Final Disposal Site and causes a high volume of waste accumulation in various regions in Indonesia, including in the Cirebon Regency.

The condition of waste accumulation in Cirebon Regency is assumed to be mostly (61\%) dominated by household (organic) waste (Sub-Directorate of Solid Waste Management, 2020), with the amount of waste heap per capita at 2,220 ml/person/day and the amount of municipal waste piling up to $4,965.30 \mathrm{~m} 3 /$ day (BPS West Java Province, 2020). This condition is exacerbated by the Covid19 pandemic, which has caused an increase in the residential sector compared to the industrial sector and the education sector. This is due to many people in Indonesia, including in the Regency Cirebon, which carries out various activities, such as working from home, studying from home, which is a demand from the government's policy regarding restrictions on activities outside the home. As a result, the total volume of waste in the Cirebon Regency has increased to around 1,198 tons/day. In contrast, the capacity of the Cirebon Regency Environmental Service and its staff has increased. Waste in Cirebon Regency is only able to manage 100 to 110 tons per day. (Dawn Cirebon, 2020).

The increasing volume of waste generation in the Cirebon Regency should require optimal management. According to (Marliani 2014), waste management that does not use environmentally friendly waste management methods and techniques will have a negative impact on health; this is because the volume of waste that is increasingly piling up can cause a foul odor that blends with plastic bags so that it can become polluted. Air that interferes with the respiratory system (Sianipar \& Simaremare, 2020). In addition, waste will significantly disrupt the preservation of environmental functions, both in the residential environment, forests, rice fields, rivers, and oceans. Efforts to 
optimize waste management can be carried out by synergizing the community to protect the environment jointly. Community participation is the mental and emotional involvement of the community to contribute to providing ideas in supporting environmental cleanliness (Yasril \& Nur, 2018). Individuals who want to protect the environment will make new activities and breakthroughs for environmental conservation.

The chain of waste handling is still a challenge because of the existence of waste generation, high costs in transporting the waste, accumulation of waste that exceeds the landfill's capacity, effectiveness, and efficiency of waste handling. Therefore, it is necessary to study the waste management chain at the district/city level. By knowing the waste handling chain, it is possible to see an overview of the waste handling problems in each chain for future improvements (Indartik et al., 2018). Departing from this, it is certainly needed in making a breakthrough by the people in Cirebon Regency to change the phenomenon of accumulation of organic waste into an opportunity that has economic value.

\section{METHOD}

The research approach used is a qualitative approach with a Participatory Research Appraisal research design. Research design Participatory Research Appraisal is research characterized by the community's active involvement as the target group. PRA research places the target group as the 'subject' in the activation process and not as the 'object.' In Participatory Research Appraisal, the researcher places himself as an 'insider' (a party within the target group who is actively involved in the activity program), not as an 'outsider' (a party outside the target group). The active involvement of the community usually marks the implementation of this research design as the target group. (Handayani, 2009).

(Adimihardja \& Hikmat, 2003) added that in the use of the Participatory Research Appraisal design approach, there are several principles for the types of planning, research, development, and program activities, including (a) Participatory Rural Appraisal, (b) Participatory Research and Development, (c) Participatory Rapid Appraisal, (d) Participatory Planning and Assessment, (e) Participatory Learning Methods, (f) Participatory Action Research and (g) Participatory Learning and Action.

The principle of the approach used in this research design is to use Participatory Rural Appraisal. Participatory Rural Appraisal (PRA) is an extension and application of waste management thinking, approaches, and methods, especially related to the concept of using organic waste in the field, the important value obtained in participant observation is to find the right perspective so that the validity of knowledge is found, which exists. The Participatory Rural Appraisal (PRA) method is a kind of "a collection of approaches and methods that enable village communities to share, develop, analyze their knowledge about existing phenomena and conditions for planning and action. This method is highly trusted for its effectiveness in running community empowerment programs (Mikkelsen, 2011).

The subjects in this study were the managers of the Community Care for the environment (coupling) and the people in the neighborhood of RT.05/RW.05, Sumber Village, Cirebon Regency. The place of research was conducted at the Kopeling location RT.05/RW.05, Sumber Village, Cirebon Regency. The focus of this research is to find out how to use the strategy. The data collection technique was carried out using in-depth interviews so that the authors obtained information directly through several questions to the informants (Indrawan \& Yaniawati, 2014). The type of interview chosen is through open and in-depth interviews. The author conducts interviews freely to dig up information as deeply as possible and as complete as possible. The researcher's understanding of the phenomena that exist is by the understanding of the actors themselves. In addition, the collection technique used is the documentation method, namely the data collection method used to trace historical data. The document method referred to in this study are books, notes, magazines, newspapers, the internet, newspapers (Bakhri et al., 2018). 


\section{DISCUSSION}

Garbage is residual waste (Rakhmawati et al., 2019) generated from the results of human activities, animals (Rahayu \& Sukmono, 2013), and natural processes that do not yet have economic value. Based on its origin, according to (Marliani, 2014), solid waste can be classified as:

1. Organic waste consists of plant and animal constituent materials were taken from nature or produced from the agricultural, fishery, or other activities. This waste is easily decomposed in natural processes. Most of the household waste is organic material. Including organic waste, such as waste from the kitchen, leftover flour, vegetables, fruit peels, and leaves.

2. Inorganic waste comes from non-renewable natural resources such as minerals and petroleum or industrial processes. Some of these materials do not occur in nature, such as plastic and aluminum. Some inorganic substances as a whole cannot be decomposed by nature, while others can only be decomposed in a very long time. This type of waste at the household level, for example, is in the form of bottles, plastic bottles, plastic bags, and cans.

Waste has long been a source of problems that includes many aspects; therefore, its management needs to be comprehensively and integrated with more good innovations in terms of all aspects, be it social, economic, and technical aspects from upstream to downstream. To provide economic benefits, be healthy for the environment, and change people's behavior means waste management needs to be done from the source.

Waste management community-based can be done using the concept of 3R (Reduce, Reuse, Recycle) to reduce waste from the source, reduce environmental pollution, provide benefits to the community, and change people's behavior toward the trash. The concept of waste management is straightforward to implement but difficult to implement. Because the success of implementing this management is very dependent on community participation by changing their behavior which is generally influenced by the socio-cultural character and socio-economic character that characterizes people's lives (Puspitawati \& Rahdriawan, 2012), therefore, it is necessary to change the paradigm of waste management as early as possible by involving the community in managing their waste.

Participation in community-based waste management is high-level participation because it is based on decisions taken by the local community (bottom-up). Community involvement in waste management is driven by their determination and awareness of the meaning of their involvement. The role of external parties is only to provide stimulus/support according to the needs decided by the local community. Community participation is in the entire waste management process, starting from decision making in identifying problems and needs, program planning, program implementation, and evaluating and enjoying program results (Puspitawati \& Rahdriawan, 2012).

The waste utilization plan is carried out through the Participatory Rural Appraisal (PRA) approach, which is a method to increase community participation in development. Robert Chambers asserts that PRA allows the community in a village to express and analyze their situation and optimally plan and implement that commitment in their village (Mikkelsen, 2011). In addition, (Hudayana et al., 2019) also explained that in the PRA approach method, village communities play an active role in mapping social problems and their causes, road maps to solve problems, and then pouring them into programs, budget support, and work-based implementation. Equality, self-reliance, and community independence. PRA is also an appropriate instrument for assessing community needs at the local level.

According to (Hudayana et al., 2019), in this PRA method, the village community is no longer the object that receives the program from above (top-down) but becomes the subject of development who designs development programs from the bottom (bottom-up) by continuing to be active in the planning process, determining the priority scale of the program, budgeting, implementing, and utilizing development outcomes that are controlled at the village level. The high participation of citizens in the village-scale development process allows the program to be implemented based on self-reliance and be more successful for their welfare. 
The researcher's position in the PRA method is as a facilitator, which makes it easier for the community to carry out the research action. With high participation in a community where community members are involved, PRA can be carried out in groups. For example, in terms of data collection, data analysis, program formulation, budget, and details of activities and their implementation. Because it acts as a facilitator, PRA activities can be successful if the community groups can be active and continue to be motivated to produce and produce them in a participatory manner.

Community-based waste management has succeeded in involving the community and has been carried out by a group of members of the Kopeling. Kopeling or Community Care for the Environment is a community that was formed in early 2020 and consisted of around 17 youths from RT.05/RW.05, Sumber Subdistrict, Cirebon Regency. The driving force for the formation of this community is the Chairperson of the Karangtaruna Regency of Cirebon, who is also a community from the RT.05/RW.05 environment of Sumber Village himself by inviting several youth organizations in the local environment.

The community was formed based on public concern and concern for the increasing accumulation of organic and inorganic waste. An increase in the volume of waste that is not matched by an increase in the quality of waste management will certainly have the potential to cause various negative impacts on the surrounding environment. Not only in terms of the environment, such as causing flooding and the potential for methane gas, garbage also has an impact on health conditions. In addition, based on the statement (Prihatin, 2020), the high volume of uncontrolled waste can lead to a decrease in size between residents and a decrease in interest.

"Initially, we were concerned about waste in our environment, and then we carried out a lot of utilization planning agendas which of course collaborated with various other communities. However, the plan was not implemented over time, so we decided to carry out our waste utilization agenda with minimal tools and personnel."

Community involvement RT.05/RW.05 Kelurahan Sumber in waste management activities starts from identifying problems and needs, planning programs, implementing programs, and evaluating programs. The waste utilization activity was started by gathering the community, especially homemakers in RT.05/RW.05, to participate in protecting the environment and at the same time utilizing waste to become economically valuable. The people of RT.05/RW.05, especially members of the Kopeling community, feel that their involvement in waste management activities is necessary. Departing from the hope of finding the best solution by accumulating household waste, the community feels that household waste management activities have economic value that needs to be carried out.

This activity was formed based on the public concern for the surrounding environment so that real action is needed to contribute to development, especially waste management. Community participation was initiated by the youth who are members of Kopeling to identify the waste management program's needs to strengthen the community's participation. In later stages, a sense of ownership will emerge for the sustainability and success of the waste utilization program.

The implementation stage of this program begins with identifying problems that are needed for the accuracy of the program objectives to be carried out. It started with an internal meeting between several youths who are members of the environmental care community to gather views related to social phenomena that exist in the RT.05/RW.05 neighborhood of the Sumber subdistrict and absorb ideas initiatives ideas from each member of Kopeling. This is very necessary because it can build intention and awareness of the phenomena that exist in the field. In addition, it is also necessary to find and align the intentions of the waste utilization program so that Kopeling members have the same spirit and goals and are directed.

The program plan is to collect household waste in the RT.05/RW.05 Kelurahan Sumber to turn it into something of economic value, for example, as compost. Until now, many innovations in waste management as agricultural and livestock fertilizer have been carried out before. Management of 
household-scale waste independently in the technical aspect is straightforward to do. Based on the previous description, waste management with the concept of zero waste still applies the principle of Reduce, Reuse, Recycle (3R) (Widiarti, 2012). The hope is to minimize piles of garbage and environmental pollution in Cirebon Regency in general, especially in RT.05/RW.05 Kelurahan Sumber, the collection of organic waste can also give birth to the potential for economic empowerment of the surrounding community through organic waste as compost.

After collecting the problem phenomena and planning solutions to the problems that have been recorded, the Kopeling youth then plunged into the community, especially mothers who were directly related to household waste. In this activity, the Kopeling youth explained the program that would be run and provided education regarding the correct way to sort waste by first explaining the difference between the components of organic waste and inorganic waste. This knowledge is essential considering that some people still do not have more knowledge related to waste management.

Saribanon (Widiarti 2012) explained that increasing knowledge would trigger the formation of individual perceptions about waste and ultimately lead to initiatives to take concrete actions to protect the environment, one of which is managing household waste. The level of knowledge contributes significantly to the formation of individual perceptions. In contrast, accessibility to information, especially regarding waste sorting and recycling, significantly contributes to individual perceptions and participation in waste management.

The success of disseminating information is indeed influenced by several factors, as described (Utami et al., 2008), including education, gender, and individual perceptions. The higher the education and the better one's perception of cleanliness, the higher the ability to sort out the waste. The female gender has a higher ability to sort their waste than the male gender. In the end, the choice of a technical zero waste-based waste management method, especially for commercial waste, will it be given to scavengers; or sold to a junkman; or saved in a waste bank, is not the essence of zero-wastebased waste management, but the most important thing is the awareness of each individual that waste must be reduced to a landfill or not in illegal landfills so that this activity can be the spearhead of overcoming the problem of organic waste that continues to experience enhancement.

After the activity, the waste utilization program began to run by starting with distributing 2 trash bins in each household so that homemakers could directly separate their organic and inorganic waste in their respective places. After collecting household waste, the coupling members then use the organic waste into compost. However, over time, the compost produced turned out to be of less economic value. Sometimes, the manager suffered losses to cover the operational costs of fertilizer processing that were not covered.

Based on this, the youth members of Kopeling then took the initiative to transfer the results of processing the organic waste as catfish feed. Since then, the Kopeling youth have sought various supports from many parties independently and through Bank BJB Sumber CSR to facilitate the management of catfish farming. Kopeling received capital assistance for drilling wells and pelletmaking tools for fish pond development from CSR Bank BJB Sumber with assistance from various parties through a community self-help system. In its implementation, the managers continue to combine other ingredients such as rice bran and other vitamins to increase the production of catfish farming.

Over time, catfish farming using feed from the processing of organic waste can show economic value. The existence of catfish farming evidence this; now, the Kopeling youth can add ponds one by one, which has amounted to 12 pounds with the original number of catfish being 2,500; now, there are approximately 20 thousand catfish. Every week, Kopeling can harvest 1-2 quintals of catfish with a turnover of between 3 to 4 million Rupiah/week. This success certainly needs to be appreciated because organic waste, which was initially a social problem, is now capable of economic value.

It is undeniable; they hope to develop catfish farming in the future are still limited to basic staples. Because the basic staples used by Kopeling only rely on waste from households in the 
surrounding environment, considering the limited operational facilities for the expansion of organic waste transportation. But fortunately, there is a private hospital, Islamic boarding school, and cafe located in Sumber Subdistrict that is willing to contribute to the running of this program. The hospital, Islamic boarding school, and café provide organic waste to Kopeling to be managed and processed into catfish feed.

However, Kopeling still has high hopes for the development of breakthroughs regarding organic waste management. With this hope, Kopeling also wants assistance from other CSRs, especially in the Sumber area, to convert waste into animal feed. In this case, the Kopeling youth have implemented organic waste into maggot cultivation feed with the same goal, namely minimizing the problem of waste originating from upstream (households) to be of economic value.

\section{CONCLUSIONS And RECOMMENDATIONS}

This study concludes that the management of household waste in RT.05/RW.05 Sumber Village, Cirebon Regency through the Participatory Rural Appraisal (PRA) method for Kopeling youth and the community in RT.05/RW.05 has resulted in active participation and good motivation. . It was said that because the Kopeling youth program (Community Concerned for the Environment) to convert organic waste into compost/catfish farming feed and selling value has succeeded in minimizing the accumulation of existing waste while being able to increase Kopeling's income even though in its implementation it still uses raw materials and operational facilities that are still underdeveloped.

\section{ACKNOWLEDGMENTS}

Thanks are given to all members of the Community Environmental Care RW.05, Sub Source, Cirebon, who was willing to provide information for the completion of the activities of this service.

\section{REFERENCES}

Adimihardja, K., \& Hikmat, H. (2003). Participatory Research Appraisal: Pengabdian dan Pemberdayaan Masyarakat. Humaniora.

Bakhri, S., Leliya, \& Purnama, L. (2018). Tinjauan Etika Bisnis Islam dalam Strategi Pemasaran Home Industri Tahu Sari Rasa. Al-Mustashfa: Jurnal Penelitian Hukum Ekonomi Syariah, 3(2), 284299.

BPS Provinsi Jawa Barat. (2020). Provinsi Jawa Barat Dalam Angka 2020.

Fajar Cirebon. (2020). Volume Sampah Rumahan Meningkat. Fajar Cirebon. https://fajarcirebon.com/volume-sampah-rumahan-meningkat/

Hudayana, B., Kutanegara, P. M., Setiadi, S., Indiyanto, A., Fauzanafi, Z., Nugraheni, M. D. F., Sushartami, W., \& Yusuf, M. (2019). Participatory Rural Appraisal (PRA) untuk Pengembangan Desa Wisata di Pedukuhan Pucung, Desa Wukirsari, Bantul. Bakti Budaya, 2(2), 3. https://doi.org/10.22146/bb.50890

Indartik, Suryandari, E. Y., Djaenudin, D., \& Pribadi, M. A. (2018). Penanganan Sampah Rumah Tangga Di Kota Bandung: Nilai Tambah dan Potensi Ekonomi. Jurnal Teknik Lingkungan, 15(3), 195-211.

Indrawan, R., \& Yaniawati, P. (2014). Metodologi Penelitian Kuantitatif, Kualitatif dan Campuran untuk Manajemen, Pembangunan dan Pendidikan (Pertama). PT Refika Aditama.

Marliani, N. (2014). Pemanfaatan Limbah Rumah Tangga (Sampah Anorganik) Sebagai Bentuk Implementasi. Formatif, 4(2), 124-132.

Mikkelsen, B. (2011). Metode Penelitian Parttisipatoris dan Upaya Pemberdayaan. Yayasan Pustaka Obor Indonesia.

Prihatin, R. B. (2020). Pengelolaan Sampah di Kota Bertipe Sedang: Studi Kasus di Kota Cirebon dan Kota Surakarta. Aspirasi: Jurnal Masalah-Masalah Sosial, 11(1), 1-16. https://doi.org/10.22212/aspirasi.v11i1.1505 
Puspitawati, Y., \& Rahdriawan, M. (2012). Kajian Pengelolaan Sampah Berbasis Masyarakat dengan Konsep 3R (Reduce, Reuse, Recycle) di Kelurahan Larangan Kota Cirebon. Jurnal Pembangunan Wilayah \& Kota, 8(4), 349. https://doi.org/10.14710/pwk.v8i4.6490

Rahayu, D. E., \& Sukmono, Y. (2013). Kajian Potensi Pemanfaatan Sampah Organik Pasar berdasarkan KarakRahayu, D. E., \& Sukmono, Y. (2013). Kajian Potensi Pemanfaatan Sampah Organik Pasar berdasarkan Karakteristiknya (Studi Kasus Pasar Segiri Kota Samarinda). Jurnal Sains \&Teknologi Lingkunga. Jurnal Sains \&Teknologi Lingkungan, 5(2), 77-90.

Rakhmawati, R., Sulistiyoningsih, M., \& Is Retnowati, E. (2019). Beternak Lele Murah Dengan Manggot Dari Limbah Pasar Sebagai Pengganti Tepung Ikan di Jatikusuma Kecamatan Mranggen. Pengembangan Sumberdaya Menuju Masyarakat Madani Berkearifan Lokal, 630-632.

Sianipar, H. F., \& Simaremare, J. A. (2020). Teknologi Pengelolaan Sampah Dalam Mengurangi Pencemaran Lingkungan Perairan. Potensi Penelitian Dan Pengabdian Di Era New Normal, 54-57.

Sub Direktorat Pengelolaan Persampahan. (2020). Rekapitulasi Data Persampahan Provinsi. Kementerian Pekerjaan Umum Dan Perumahan Rakyat. http://ciptakarya.pu.go.id/plp/simpersampahan/baseline/ rosampahdataproplist.php?id=3200\&tabid=dataumum

Utami, B. D., Indrasti, N. S., \& Dharmawan, A. H. (2008). Pengelolaan Sampah Rumah Tangga Berbasis Komunitas: Teladan dari Dua Komunitas di Sleman dan Jakarta Selatan. Sodality: Jurnal Transdisiplin Sosiologi, Komunikasi, Dan Ekologi Manusia, 2(1), 49-68. http://jurnalsodality.ipb.ac.id/jurnalpdf/edisi4-3.

Widiarti, I. W. (2012). Pengelolaan Sampah Berbasis "Zero Waste" Skala Rumah Tangga Secara Mandiri. Jurnal Sains \&Teknologi Lingkungan, 4(2), 101-113. https://doi.org/10.20885/jstl.vol4.iss2.art4

Yasril, Y., \& Nur, A. (2018). Partisipasi Masyarakat Dalam Pemberdayaan Lingkungan. Jurnal Dakwah Risalah, 28(1), 1. https://doi.org/10.24014/jdr.v28i1.5538 


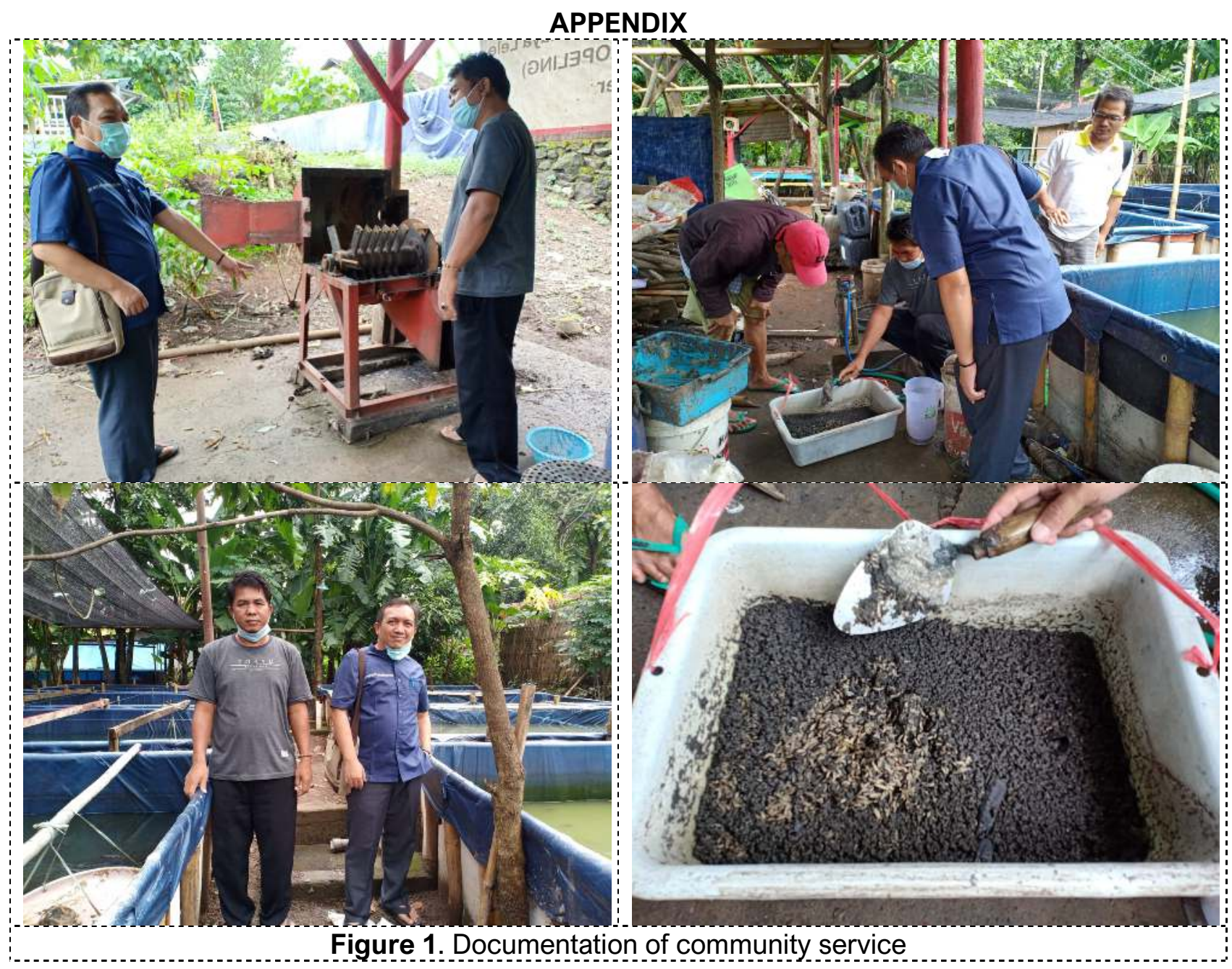

